\title{
Fostering Peer Collaboration Skill Development at the Tertiary Level
}

\author{
Vineta Apse ${ }^{1}$ MBA, Ed.M.; Monta Farneste ${ }^{2}$ Dr.paed. \\ University of Latvia, Latvia \\ vineta.apse@lu.lv¹; monta.farneste@lu.lv²
}

\begin{abstract}
Peer work at tertiary level, especially in writing classes, emphasising peer editing, has been studied frequently around the world, but there is no available research in Latvia when students collaborated not only in improving their papers, but also in writing them. Therefore, the goal of the present study was to find out undergraduate students' perception about a successful peer collaboration in such a context and whether group work assignments are useful. An authors' designed questionnaire survey was used as the main research method. 162 undergraduate students from three universities and three various study programmes participated in the research. The results show that $53 \%$ of the respondents considered working in groups, when writing group papers / reports useful or very useful, but the results vary when the answers of the students of different study programmes are compared, with the philology students tending to value these assignments higher. The majority of the students also considered that they would need the skills developed during the collaboration, but most of them disagreed that this collaboration helped them to improve their writing skills. The most useful experience during the peer collaboration, according to the respondents, is idea generation. Because fostering teamwork skills is being emphasized more and more as one of the skills at tertiary level and because advanced writing skills are demanded by employers, the authors conclude that an academic writing course where peer collaboration is practised needs to be included in all university study programmes.
\end{abstract}

Keywords: university education, peer collaboration, academic writing, undergraduates, group report.

\section{Introduction}

Peer work has been of constant interest among scientists, including teachers, in different levels: primary level (Philippakos, 2017; Stramkale, 2018), secondary level (Taar, 2013), tertiary level (Guardado, Shi, 2007; Goldin, Ashley, Schunn, 2012; Barnard, de Luca, Li, 2015), as well as professionals (e.g. peer writing groups among colleagues) (Myatt, Edwards, Bird, 2014). It has been emphasised that student collaboration should be started with a discussion of the task, not only an analysis of papers written by their peers (Bruffee, 1980; Bruffee, 1984; Dobao, Blum, 2013). As it is highlighted in the documents meant for teaching languages (Common European Framework..., 2001, 19), the need for peer collaboration has become a way of learning in English as a Foreign Language (EFL) classes. Abilities to provide constructive pair and group work are important for a further career; thus, such skill development should have been focused on at universities. As to the classes of academic writing at tertiary level, students might doubt about peers' competence in contrast to the teacher's experience. When learning at school, students receive the teacher's feedback and cannot imagine that a peer might provide a reliable feedback as a teacher does. Moreover, students themselves frequently do not feel secure about their own knowledge, namely, whether their papers are well-written. In fact, they do not realize benefits of peer collaboration before they have experienced that in the classes of such a course as academic writing.

Prior studies held in Latvia emphasized that EFL undergraduates are positive towards peer feedback on their papers (Farneste, 2005a). They stressed that peers mainly focused on grammar, then organization and spelling, but seldom on content, layout and punctuation (Farneste, 2005a, 31). As the authors had expected feedback on language and organization, it is clear why they were positive towards peer work (Farneste, 2005a, 29). Those students who claimed that they did not like to provide peer feedback in the classes of writing explained that it was difficult to notice mistakes, that they could misunderstand peers and make wrong corrections, it was difficult for them to verbalize their suggestions how to improve the papers (Farneste, 2005b, 18). The genre-process approach (Flowerdew, 1993; Badger, White, 2000; Hyland, Hyland, 2006) to teaching writing has ensured that students learn not only about the genres they need in communicating with academic community, but also how to work at their papers starting with drafting, writing and ending with proofreading of the paper before its submission for grading. 
Collaboration is essential in professional life; therefore, these skills should be developed while studying. A. Burke (2011) in her study emphasized that group mates help not only to master the themes better, but also to develop teambuilding skills. In order to ensure a successful group work, learners need to be instructed how to do that, namely, their responsibilities and assessment criteria (Burke, 2011, 90-91). Learners should be given grading rubrics for 'the group process and final product' where the first would focus on active student collaboration and expertise in the task performance, while the second, on the assessment criteria of a text (Burke, 2011, 92). B.H.H. Golsteyn, A. Non and U. Zölitz's $(2017,18)$ study demonstrated that 'more persistent peers and less risk-tolerant peers achieve higher grades.' However, 'peers' self-confidence or anxiety [did not] affect their performance'. It was interesting that highly persistent peers could successfully collaborate with less-persistent ones in order to have good results in performance (Golsteyn, Non, Zölitz, 2017, 18-19).

C. Lau Chun Yun (2006) claimed that collaboration, although proved to be effective, is neglected at tertiary level. He emphasized that the skills developed while collaborating with peers will be useful in their career (Lau Chun Yun, 2006, 287). Among such reasons was mentioned that an employee should be able not only to collaborate, but also be autonomous while performing his/her duties (Lau Chun Yun, 2006, 288). The small-scale study of second-year pre-university students enrolled in a Commerce Mathematics class demonstrated that peer collaboration had a positive result in the studies, as it helped to develop leaners' interaction as well as communication skills (Lau Chun Yun, 2006, 295). E.H. Chiriac and K.F. Frykedal $(2011,3)$ pointed out that group work at school involved not only 'different challenges', but also 'enjoyment for both the teacher and the students. They also emphasized two types of group work: 'working in a group' and 'working as a group' (Chiriac, Frykedal, 2011, 3). Therefore, two types of group work can be distinguished: one of them when students work together to reach some aim, and the other, when students work separately by doing their small task in the whole task (Chiriac, Frykedal, 2011, 3-4). They also emphasized that not only the subject, but also group work needs appropriate pre-teaching: '(a) how to structure group work, (b) take different roles or (c) handle group processes' (Chiriac, Frykedal, 2011, 9); however, the teachers seem to be reluctant to use it in their classrooms because they 'lack experience' how to help 'to develop the ability to collaborate' rather than 'to acquire subject knowledge' (Chiriac, Frykedal, 2011,12).

D. Hennessy and R. Evans (2006) contrast collaborative learning with peer cooperation. If peer cooperation is more focusing on task completion of the task as the teacher requires, collaboration, in its turn, envisages active involvement 'in the teaching and learning process', namely the students are organizing themselves with little intervention of the teacher (Hennessy, Evans, 2006, 97). D. Hennessy and R. Evans state that the teacher only deals with the product, not the process of student collaboration, which allows students to debate and make their own choices.

As seen from the papers discussed above, fifteen years have passed since the prior research in Latvia on tertiary level student collaboration on their academic essays (Farneste 2005a; Farneste 2005b). However, no research has been held in Latvia when students collaborated not only in improving their papers, but also in writing them. Thus, the present study will focus on finding out undergraduate students' perception about a successful peer collaboration in such a context and whether group work assignments are useful.

\section{Methodology}

As peer collaboration is a form of learning fostered in all universities, but because the authors of the research have met explicitly and implicitly individually expressed dissatisfaction with group work assignments, when students know they are going to be graded, it was decided to study the students' perception about a successful peer collaboration during group work assignments and whether such assignments are useful. The following research questions were posed: (1) What do students understand as a successful peer work? (2) What knowledge can they share in the classes of writing?

The research method was a survey, based on a questionnaire designed by the authors of the paper. The questionnaire contained 6 questions, two of which referred to data about the respondents, that is, the study year they were in (second or third) as only the ones with some experience in peer collaboration when writing papers and reports were selected for the research. One question was asked to find out whether the respondent was a student in a full programme or an Erasmus+ exchange student. The other questions 
asked for the respondents' opinion on how useful they considered peer collaboration, which aspect of writing, for example idea generation, planning the paper, proofreading etc. they considered most useful during the peer work, as well as whether the respondents thought that peer collaboration helped them to develop their writing skills and that the skills developed during the peer collaboration activities would help them in their future career. The questionnaire used closed questions, where the respondents were asked to select one answer that suits them. Questions 5 and 6 also contained an added open-end question requesting the respondents to state why they considered that peer collaboration while writing had not helped them to develop their writing skills or would not be useful in their future career, but as very few answers were received, these responses will not be analysed within the framework of this paper.

The research was a case study as it comprised surveying undergraduates of only five groups studying English Philology, two groups studying Tourism and Hospitality Management in English and two groups studying Public Relations and Advertising Management (only some of the subjects in this programme are delivered in English). Thus, the case study included three higher educational establishments in Latvia and was conducted over a period of two years - 2018 and 2019. The English Philology students have several courses in academic writing where emphasis is placed on developing their peer editing skills, as well there are some subjects where students are asked to deliver group reports. The students of the other two programmes are frequently asked to deliver a report as a final product of a group work assignment in the content subjects they are taking. The group report assignments require both peer collaboration and peer cooperation.

During the survey the students had to evaluate how useful the peer collaboration was, and what aspects of collaboration they considered most useful. They were also asked to express their opinion whether peer collaboration could help them to develop their writing skills as well as if the skills gained during peer collaboration would be needed during their future career.

The questionnaire was distributed in paper form, and 162 completed questionnaires were received. The respondent body consisted of 53 second-year English Philology students and 6 students who were EARSMUS + exchange students in the programme, 94 third-year students from the other two programmes, among which 26 were international students who had been enrolled in a full programme, and the remaining 15 students were EARSMUS + exchange students.

\section{Results and discussion}

As the survey results indicate (Figure 1), the majority of the respondents (68) considered working in groups when writing group reports or papers 'useful' or even 'very useful' (18 respondents), which in total results in $53 \%$ of positive response of the entire group of respondents. The $24 \%$ (or 39 students) of those who selected the response 'partly useful' could also be added to this group as they were suggesting that they still developed some useful skills during the group work writing activities. $20 \%$ (or 32 students) considered peer work 'not useful at all'. Taking into consideration the requirement to emphasise developing and fostering undergraduates' teamwork skills while at the university, this is a relatively large number of students who consider peer collaboration not useful, and the reasons for such an opinion need to be further investigated.

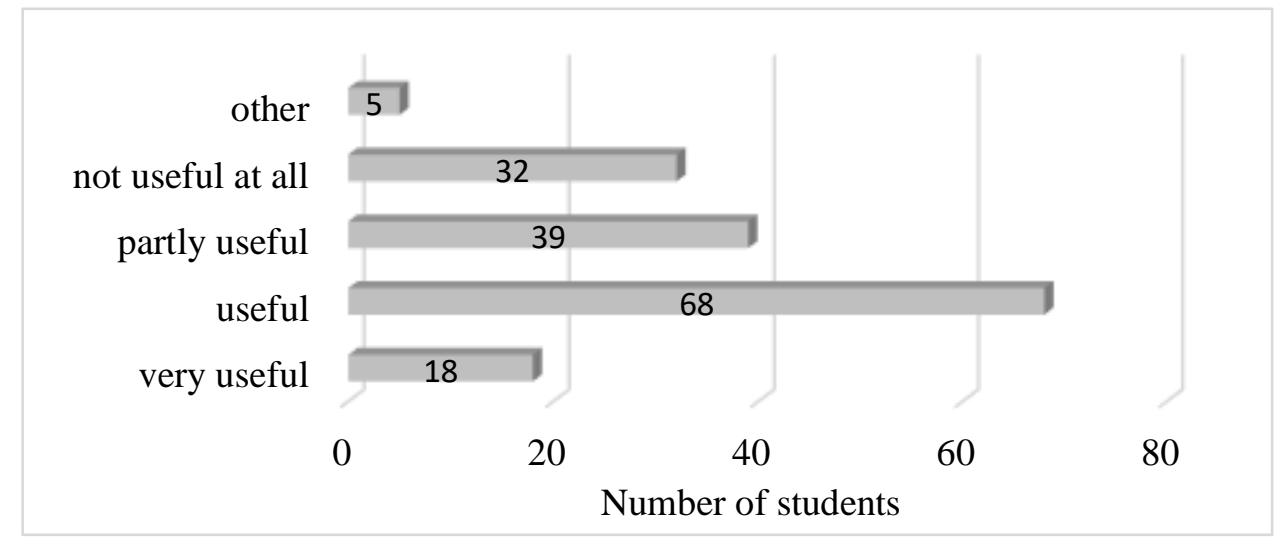

Figure 1. Usefulness of collaboration while writing a group report / paper. 
The results are slightly different, however, when the answers are compared across the programmes in which the students are studding. Only $33 \%$ of the respondents in the Public Relations and Advertising Management programme considered peer collaboration 'very useful' or 'useful' and $27 \%$ called it 'not useful at all', while $69.5 \%$ of the English Philology students and $53 \%$ of the students of Tourism and Hospitality Management programme considered it 'very useful' and 'useful'. A potential cause for such a striking difference could lie in the approaches the teaching staff use and assess group writing assignments, for example, is it peer collaboration or just per cooperation that is demanded to fulfil the assignment? The latter is usually liked less as students need to organise the entire research and writing process themselves, and it is difficult. However, the ability to plan and organize one's work and to collaborate in a group is valued high by the employer. Other causes for the observed difference in opinions might be the students' previous experience with such assignments and their ability to cope with the various roles group work assignments pose, as well as the students' individual qualities and many other factors.

It was also in the research interest to study the particular experience the students had while working together on writing assignments. Therefore, they were asked to evaluate the usefulness of their experience regarding various aspects of writing skills.

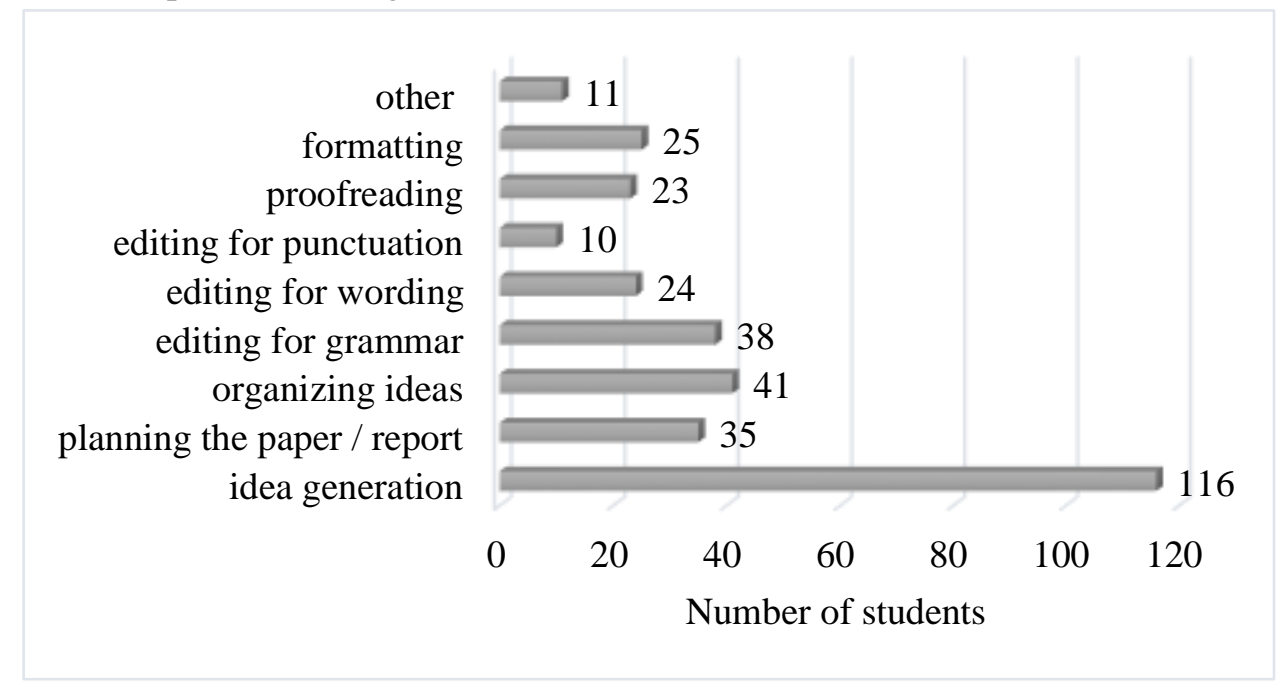

Figure 2. The most useful experience during peer collaboration writing activities.

Figure 2 demonstrates that the respondents considered idea generation as the most useful activity during the assignments (116 respondents), while the other useful experiences (organizing ideas, editing for grammar, planning the paper / report) were also considered useful but selected by a considerably less number of respondents (41, 38 and 35 respectively). The least useful activities, according to the respondents, were editing for punctuation and other not indicated in the answer choices (11 and 10 respondents). This allows the authors to assume that collaborating while writing including peer editing, although paid attention to during the academic writing courses at tertiary level, is not considered applicable by the students and they prefer to do this alone. However, idea generation and discussions about the content of the paper / report are considered as valuable activities. The reason might be that students had been practising this during classes more than writing and peer editing.

When asked directly if peer collaboration can help to develop their writing skills, $53 \%$ of the respondents replied in the negative. However, when the answers are compared across the study programmes, it is observed that English Philology students considered peer collaboration useful in order to develop their writing skills as 50 (out of 59) agreed with the statement (Figure 3). The result is not surprising, because English Philology students definitely have more academic writing courses and classes than the undergraduates of the other two programmes; thus, they have obviously managed to see the benefits of peer collaboration in writing assignments in practice.

The students were also asked to express their opinion on whether they would need the skills developed during the peer work activities, to which $78 \%$ (127 students) responded affirmatively while a rather large group (22\% or 35 students) considered them not applicable in the future. This result raises a question why the students have developed this perception and what the university teaching staff could do to change it. 
PR and Advertising Management students

Tourism and Hospitality Management students

English Philology students

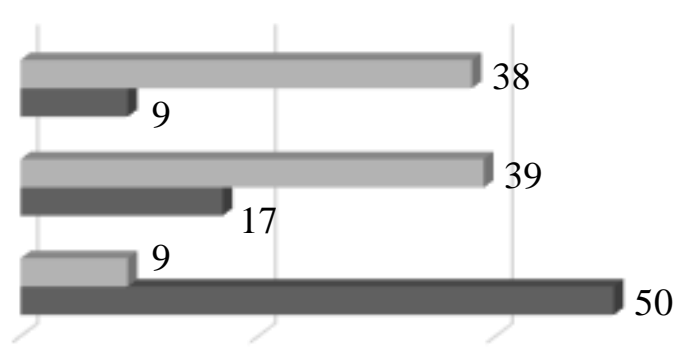
0
20
40
No $\quad$ Yes Number of students

60

Figure 3. Students' perception if peer collaboration can help to develop their writing skills.

\section{Conclusions}

Although the above described research was only a case study, the findings of the survey allow the authors to conclude on the following:

1. The majority of the respondents considered peer collaboration in writing assignments very useful or useful while the opinions differed when the responses of the students from various programmes were compared. However, employers require all their employees, not just graduates of philology programmes, to demonstrate good writing skills.

2. The respondents considered idea generation the most useful activity of peer collaboration. This is an indication that the other activities need to be practised more to change the current students' perception.

3. Only the English Philology students considered peer collaboration while writing as something that could help to improve their overall writing skills.

4. Students' experiences with peer collaboration in writing assignments, including exposure to teaching it, vary and therefore shape their perceptions whether peer collaboration is useful at all and applicable in their future.

5. In writing classes students could share their knowledge on grammar, punctuation, wording and organizing ideas logically as some of these already appeared as the respondents' choices for useful experience while working on writing assignments together with peers; thus, they need to be practised more.

6. All the above indicates why more emphasis on peer writing and collaboration should be placed in tertiary level courses and why academic writing courses where peer collaboration is practised need to be included in all undergraduate study programmes.

7. The research results also implicitly suggest that to demand students to write papers and reports together as part of a peer cooperation activity may be successful only if these tasks are first used as part of peer collaboration assignments, which could teach the students how to successfully work in a team with various people and, thus, make them more self-confident, as well as convince that peer collaboration is a useful skill to possess for the future career.

\section{Bibliography}

1. Badger R., White G. (2000). A process genre approach to teaching writing. ELT Journal, 54(2), 153-160. doi: 10.1093/elt/54.2.153

2. Barnard R., de Luca R., Li J. (2015). First-year undergraduate students' perceptions of lecturer and peer feedback: a New Zealand action research project. Studies in Higher Education, 40(5), 933-944. doi: 10.1080/03075079.2014.881343

3. Bruffee K.A. (1980). A Short Course in Writing. Practical Rhetoric for Composition Course, Writing Workshops, and Tutor Training Programs. Boston: Little, Brown and Company. 
4. Bruffee K.A. (1984). Collaborative learning and the "Conversation of Mankind". College English, 46(7), 635-652.doi: 10.2307/376924

5. Burke A. (2011). Group work: how to use groups effectively. The Journal of Effective Teaching, 11(2), 87-95. Retrieved from https://uncw.edu/jet/articles/vol11_2/burke.pdf

6. Chiriac E.H., Frykedal K.F. (2011). Management of group work as a classroom activity. World Journal of Education, 1(2), 3-16. doi: 10.5430/wje.v1n2p3

7. Common European Framework of Reference for Languages: Learning, teaching, assessment. (2001). Council of Europe Cambridge, UK: Cambridge University Press. Retrieved from https://rm.coe.int/16802fc1bf

8. Dobao A.F., Blum A. (2013). Collaborative writing in pairs and small groups: Learners' attitudes and perceptions. System, 4l(2), pp. 365-378. doi: 10.1016/j.system.2013.02.002

9. Farneste M. (2005a). Benefits and drawbacks of peer co-operation in the course of academic writing. In A. Veisbergs (Ed.), Contrastive and Applied Linguistics, XIII. Rīga: Latvijas Universitāte, Moderno valodu fakultāte, 20-37.

10. Farneste M. (2005b). Developing peer feedback skills at the tertiary level. In N. Trofimova (Ed.), Zinātnisko rakstu krājums Valoda-2005, Lingvistikas didaktikas problēmas, XIV-XV. Daugavpils Universitāte: Saule, 15-20.

11. Flowerdew J. (1993). An educational, or process, approach to the teaching of professional genres. ELT Journal, 47(4), 305-316. doi: 10.1093/elt/47.4.305

12. Goldin I.M., Ashley K.D., Schunn C.D. (2012). Redesigning educational peer review interactions using computer tools: an introduction. Journal of Writing Research, 4(2), 111-119. doi: 10.17239/jowr-2012.04.02.1

13. Golsteyn B.H.H., Non A., Zölitz U. (2017). The impact of peer personality on academic achievement. Working Paper Series, Working Paper No. 269. University of Zurich. doi: $10.5167 /$ uzh-141964

14. Guardado M., Shi L. (2007). ESL students' experience of online peer feedback. Computers and Composition, 24, 443-461, doi: 10.1016/j.compcom.2007.03.002

15. Hennessy, D., Evans, R. (2006). Small-group learning in the community college classroom. The Community College Enterprise, 12(1), 93-110. Retrieved from https://eric.ed.gov/?id=EJ846009

16. Hyland K., Hyland F. (2006). Feedback on second language students' writing. Language Teacher, 39(2), 77-96, doi: 10.1017/S0261444806003399

17. Lau Chun Yun C. (2006). What effects does peer group study have on students' learning in commerce mathematics? A case study of diverse ethnic learning. In Proceedings of the EDU-COM 2006 International Conference Engagement and Empowerment: New Opportunities for Growth in Higher Education. Australia, Perth Western: Edith Cowan University, 287-298. Retrieved from http://ro.ecu.edu.au/ceducom/85

18. Myatt P., Edwards A., Bird F. (2014). Achieving greater productivity with a peer writing group. In Proceedings of the Australian Conference on Science and Mathematics Education. Sydney: University of Sydney, 140-148 Retrieved from https://openjournals.library.sydney.edu.au/index.php/IISME/article/download/7672/8119

19. Philippakos Z.A. (2017). Giving feedback: preparing students for peer review and self-evaluation. The Reading Teacher, 71(1), 13-22. doi: 10.1002/trtr.1568

20. Stramkale L. (2018). Student's Communication Activity in Small Group Learning. In V. Dislere (Ed.), The Proceedings of the International Scientific Conference Rural Environment. Education. Personality. (REEP), 11. Jelgava: Latvia University of Life Sciences and Technologies, 25-32. doi: 10.22616/REEP.2018.029

21. Taar J. (2013). Student-student interaction during group work tasks in home economics lessons. In V Dislere (Ed.) Proceedings of the International Scientific Conference Rural Environment. Education. Personality (REEP), 6. Jelgava: LLU, 256-266. Retrieved from https://llufb.llu.lv/conference/REEP/2013/Latvia-Univ-Agricult_REEP_2013_ISSN_2255808X-256-263.pdf 